\title{
Characteristics of Active Carbon from Utilization of Red Chili Trees (Capsicum annuum L)
}

\author{
Ni Made Dwidiani ${ }^{\mathrm{a}}$, Putu Wijaya Sunu ${ }^{\mathrm{b}}$, Gusti Ngurah Nitya Santhiarsa ${ }^{\mathrm{c}, *}$ \\ ${ }^{a}$ Udayana University, Indonesia. Email: dwidiani@gmail.com \\ bBali State Politechnic, Indonesia. Email: wijayasunu@pnb.ac.id \\ 'Udayana University, Indonesia. Email: santhiarsa@yahoo.com
}

\begin{abstract}
This work studies the use of red chilli tree (capsicum anuumm L) waste as material of activated carbon and examines the morphological structure and elemental composition of the activated chili trees. The morphological structure was measured at TekMIRA (Pusat Penelitian dan Pengembangan Teknologi Mineral dan Batubara, Bandung) by using the scanning electron microscope (SEM), and the composition of the elements of carbon, hydrogen, nitrogen and ash is determined by the ultimate testing analysis with the ASTM D5373 standard. In the testing procedure, activated carbon is made from red chili tree waste by dehydration with a temperature of $2000 \mathrm{C}$ for 1 hour and carbonized with a temperature of $3750 \mathrm{C}$ for 1 hour. Then, the chemical activation $(\mathrm{NaOH})$ is made in variation of concentration of $1 \%, 3 \%$, and $5 \%$ with soaked time 24 hours, and dried at $2000 \mathrm{C}$ for one hour. The carbonization at a concentration of $1 \%(\mathrm{NaOH})$ gave the best result on activated carbon from red chili trees.
\end{abstract}

Keywords: Activated carbon; capsicum annuum L.; carbonization; red chili tree waste

\section{Introduction}

Activated carbon is a type of carbon with low-volume pores that is formed to increase the surface area, and mostly used to adsorb other substances or to cause chemical reactions. Since the activated carbon has high degree of micro-porosity, one particle has considerable surface area, for example, in excess of a few square meters. With such large surface area, useful application may be obtained solely from porosity, but also additional chemical treatment increases adsorption property.

In this research, activated carbon is made from red chili tree by utilizing waste from the harvest done by farmers in Bangli, a regency (kabupaten) of Bali, Indonesia. Stems of chili trees have round and smooth, hard and woody structure with color of dark green and have many branches. In scientific classification of biology (botany), capsicum annuum is classified as Kingdom: Plantae, Clade: Angiosperms, Eudicots, Asterids, Order: Solanales, Family: Solanaceae, Genus: Capsicum, Species: C. annuum. In the binomial name (i.e., naming using a combination of Genus and Species), it is called "Capsicum annuum L.".

Chili plants belong to plants that produce seeds (Spermatophyta). Chili seeds are covered by the skin of the fruit, so then they are included in the group of closed seed plants (Angiosperms). The institution on chili seeds

${ }^{*}$ Corresponding author. Tel.: +82-2-880-7008

Fakultas Teknik Jimbaran, Udayana University, Jl. Kampus Bukit Jimbaran, Bali, Indonesia is divided into two leaf institutions, so it is included in the class of split seed plants (Dicotyledoneae). Leaves of chili plants are light green to dark, leaves are supported by leaf stalks. Pinnate leaf bone. Overall the leaf shape of a large chili plant is oval with tapered leaf tips [1]. Based on this, red chili trees are included in hardwood or hardwood with a composition of $43 \%$ cellulose, $25 \%$ hemicellulose, $16 \%$ lignin, $0.6 \%$ ash and $15.4 \%$ are other extractive parts [2]. With this composition the red chili tree waste is expected to have characteristics and good quality for active carbon material.

\section{Basic Approach}

In general terms, activated carbon is an amorphous compound that is produced from material containing carbon or charcoal that specially induces high adsorption power. Activated carbon can adsorb gases and certain chemical compounds or selective adsorption properties, depending on the size or volume of pores and surface area. The absorption of activated carbon is very large, which is $25-100 \%$ of the weight of activated carbon [3].

\subsection{Scanning electron microscope (SEM)}

Scanning Electron Microscope (SEM) is an electron microscope used as a means of detecting objects on a very small scale. In this study, SEM is used to determine the structure and pore size. The working principle of SEM is the detection of electrons scattered from a continuous high-energy electron beam accelerated in an 
electromagnetic coil, and the coil is connected to a cathode ray tube so that information is generated about the surface state of a compound sample.

Before applying SEM, sample preparation was carried out by solvent removal, sample selection and coating. When electrons with sufficiently large energy pound on the sample, it causes X-ray emissions whose energy and intensity depend on the elemental composition of the sample [4]. The detector inside SEM collects reflected electrons and determines the location of the signals with the highest intensity. The direction of detected signals informs the surface profile of the object.

\subsection{Ultimate analyzer (UA)}

The objective of using Ultimate Analyzer (UA) is to measure the amount of carbon $(\mathrm{C})$, hydrogen $(\mathrm{H})$, oxygen $(\mathrm{O})$, and other elements. The measurement test was conducted by TekMIRA(Bandung) for ash on activated carbon.

\section{Research Method}

\subsection{Materials and tools}

The materials used in this study were red chili trees, $\mathrm{NaOH}$ solution, aquades and silica sand. The tools used were knives, earthenware jars, ovens, scales, thermocouples, mortals, 35 mesh sieves, $\mathrm{pH}$ meters, ovens, furnaces. Scanning Electron Microscope (SEM) was used to determine the pore structure of activated carbon, and Ultimate Analyzer to find out carbon, nitrogen and hydrogen content.

\subsection{Testing methods}

After the necessary treatment on the material samples in 3.1, Scanning Electron Microscope (SEM) was applied to find out the morphology of activated carbon. As mentioned, the measurement was done at TekMIRA (Bandung). The ultimate test was carried out based on a standard procedure described in ASTM D5373 to find out carbon $(\mathrm{C})$, hydrogen $(\mathrm{H})$, and nitogen $(\mathrm{N})$ in the ash content.

\section{Results and Discussion}

\subsection{Scanning electron microscope (SEM)}

Scanning Electron Microscope (SEM) testing aims to determine the morphology of activated carbon including pores, and to determine the amount of volatile (impurity). The SEM test results are shown in Fig. 1(A) with $1 \%$ $\mathrm{NaOH}$, (B) $3 \% \mathrm{NaOH}$ and (C) $5 \% \mathrm{NaOH}$. These SEM image show the carbon morphology of the active red chili tree with a magnification of $1,500 \mathrm{x}$ the scale of the image is $10 \mu \mathrm{m}$.

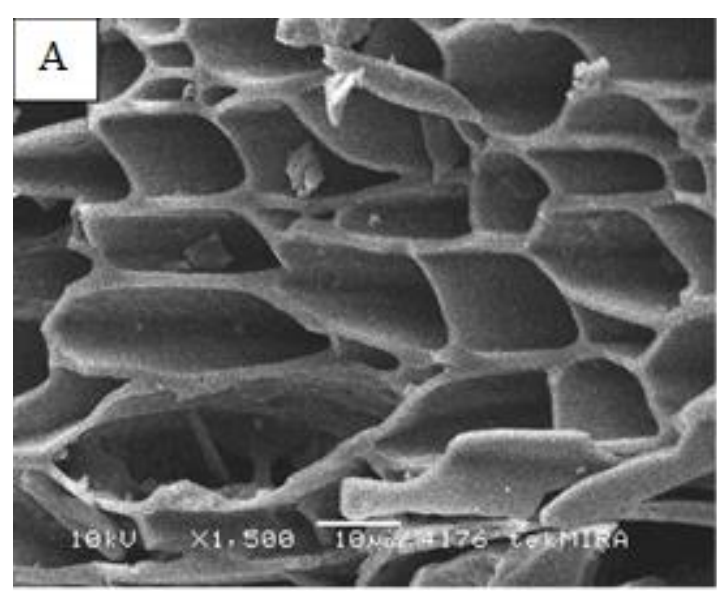

(A) $1 \% \mathrm{NaOH}$

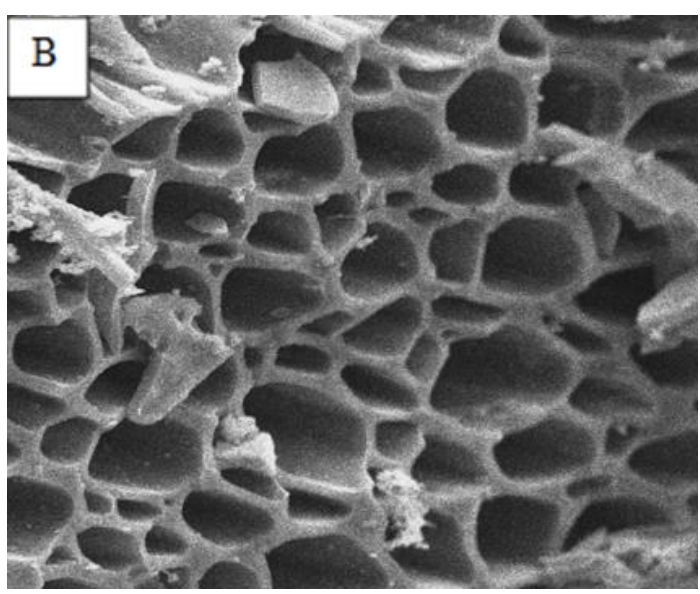

(B) $3 \% \mathrm{NaOH}$

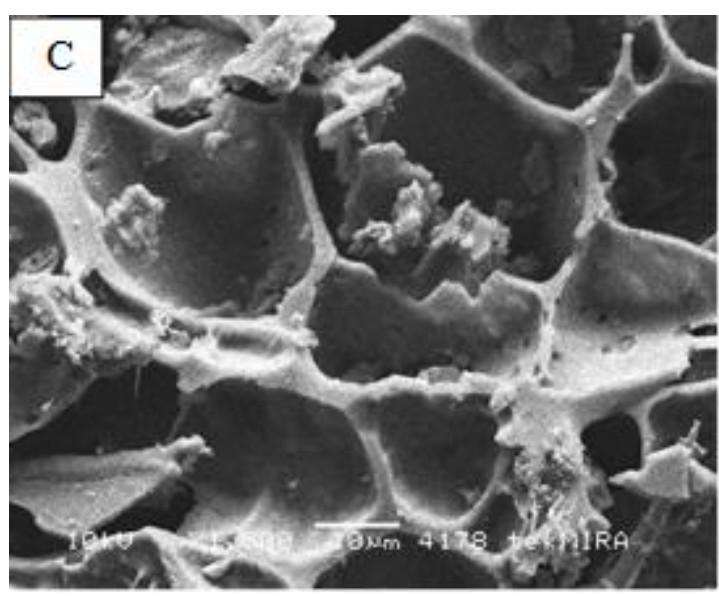

(C) $5 \% \mathrm{NaOH}$

Figure 1. Photo of surface observed by SEM 


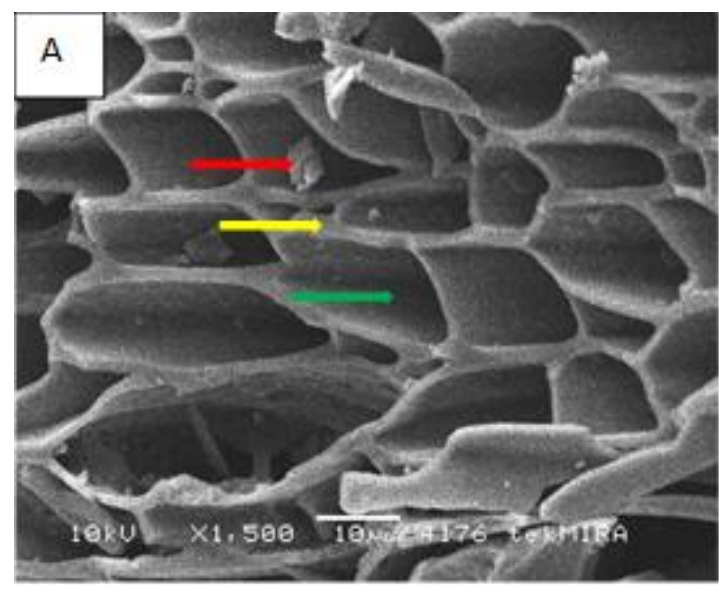

(A) $1 \% \mathrm{NaOH}$

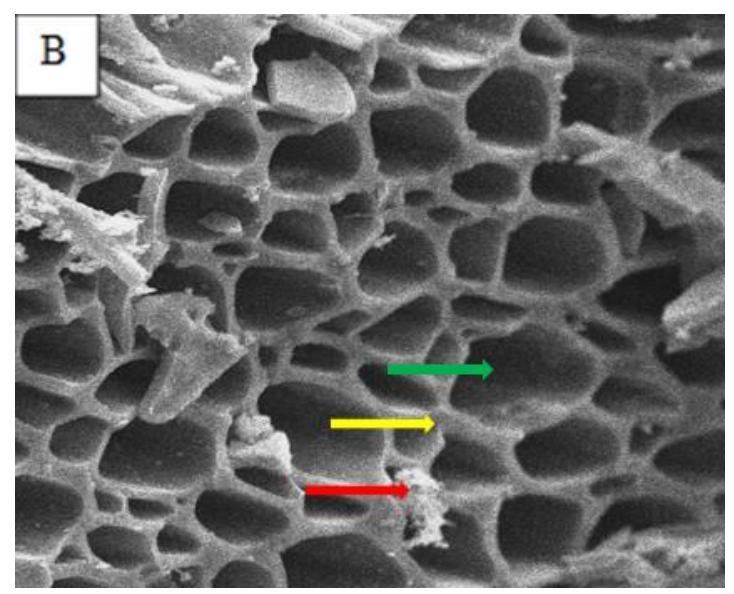

(B) $3 \% \mathrm{NaOH}$

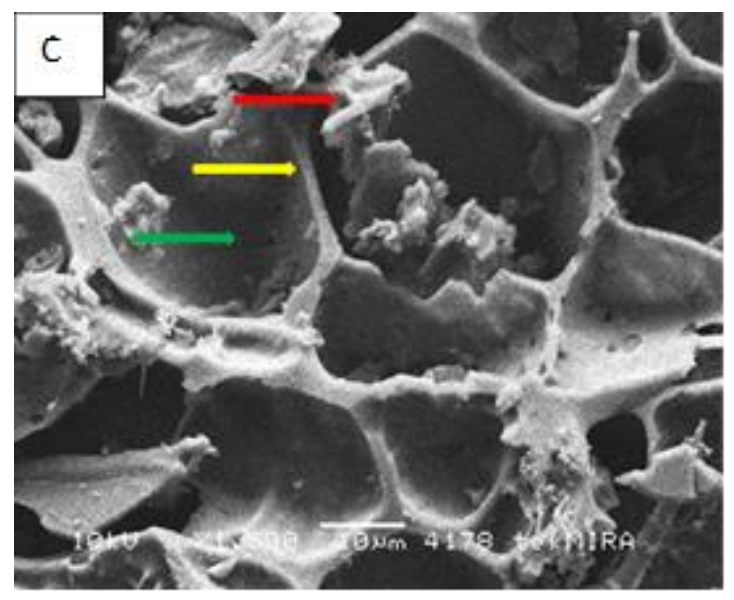

(C) $5 \% \mathrm{NaOH}$

Figure 2. Volatile, pore wall and pore on the surface

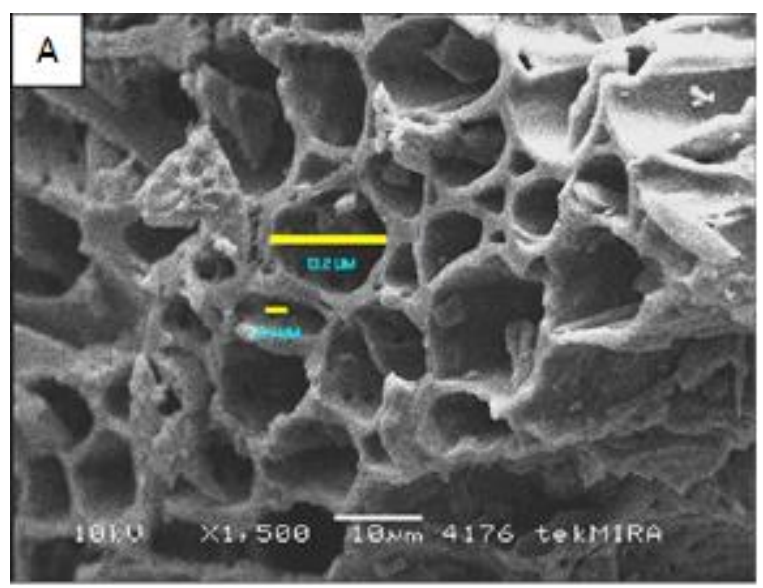

(A) $1 \% \mathrm{NaOH}$

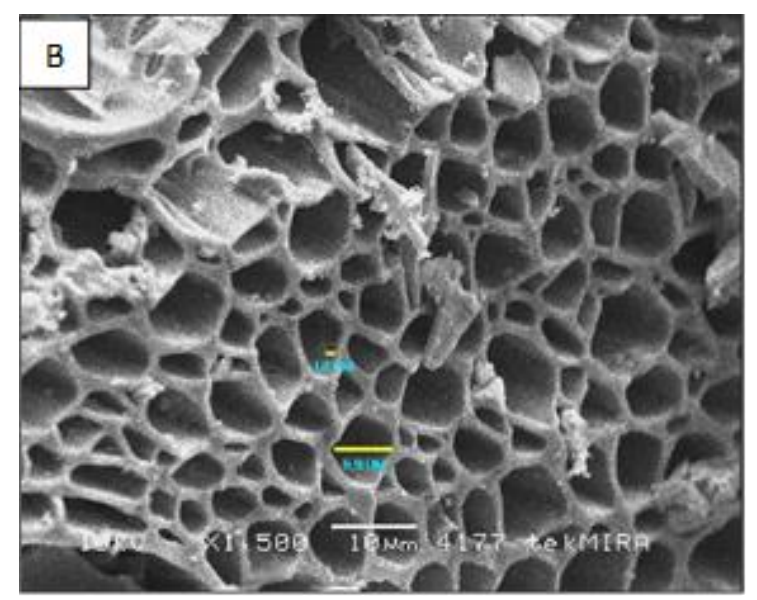

(B) $3 \% \mathrm{NaOH}$

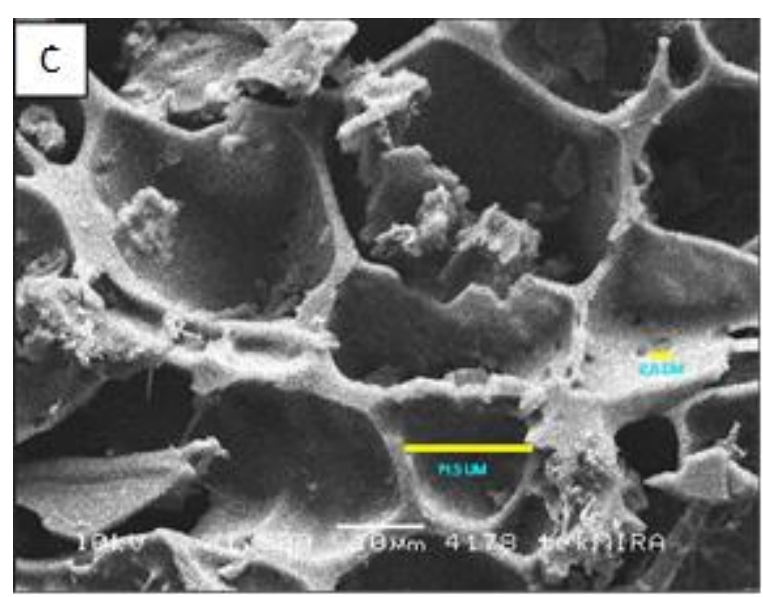

(C) $5 \% \mathrm{NaOH}$

Figure 3. Measurement of sizes on the surface 


\subsection{Shape}

In Fig. 1(A) with the $1 \% \mathrm{NaOH}$ activation, it appears that the pores formed are predominantly squares and the walls of the pores are thin. In Fig. 1(B) with the $\mathrm{NaOH}$ activation $3 \%$, the pores form circles dominantly and the wall of the pores are thicker. For maximum $\mathrm{NaOH}$ in Fig. $1(\mathrm{C})$, the pores formed begin to be irregular and the walls of the pores are very thin. Based on the shapes of the pores in the image, activation with $\mathrm{NaOH}$ with increasing concentration can affect the amount of pores formed on the activated carbon observed surfaces of the samples after treatment of different $\mathrm{NaOH}$ concentration.

\subsection{Analysis of section}

There are several parts in the image of SEM Scanning Electron Microscope activated carbon from the waste of the red chili tree shown in the image of Fig. 2(A), (B) and (C) for $1 \% \mathrm{NaOH}, 3 \% \mathrm{NaOH}$ and $5 \% \mathrm{NaOH}$ activated carbon, respectively. In the figure, red arrow indicates volatile, yellow arrow does the pore wall, and green line does pores.

\subsection{Size}

In SEM image the activated carbon from the waste of red chili tree (capsicum annuum L.) has a magnitude, among others, is the large pore diameter. Based on the picture in Fig. 3 with SEM photos from different angles in part (A) with $\mathrm{NaOH}$ activation $1 \%$ the average pore diameter is $13.2 \mu \mathrm{m}$ and the largest pore diameter on the pore wall is $2.4 \mu \mathrm{m}$, for Fig. 3(B) with the activation of $3 \% \mathrm{NaOH}$ the average pore size is $6.9 \mu \mathrm{m}$, and the pore diameter on the pore wall is $1.2 \mu \mathrm{m}$. In Fig.3(C) activation with $5 \% \mathrm{NaOH}$ with a large pore diameter averaged 14.5 $\mu \mathrm{m}$, and the pore diameter on the pore wall is $2.5 \mu \mathrm{m}$.

\subsection{Ultimate test}

The ultimate test aims to determine the content of elements that exist in activated carbon. Tests include carbon content $(\mathrm{C})$, hydrogen content $(\mathrm{H})$, nitrogen $(\mathrm{N})$, and ash content.

Table 1. Test data of the ultimate analyzer

\begin{tabular}{cccc}
\hline \multirow{2}{*}{ Elements } & \multicolumn{3}{c}{ Content (\%) } \\
\cline { 2 - 4 } & \multicolumn{3}{c}{ Treatment } \\
\cline { 2 - 4 } & $1 \%$ & $3 \%$ & $5 \%$ \\
\hline Carbon & 67.73 & 53.92 & 51.40 \\
\hline Nitrogen & 1.38 & 1.57 & 1.29 \\
\hline Hidrogen & 4.03 & 3.51 & 3.29 \\
\hline Ash & 6.28 & 20.30 & 22.23 \\
\hline
\end{tabular}

(a) Carbon content

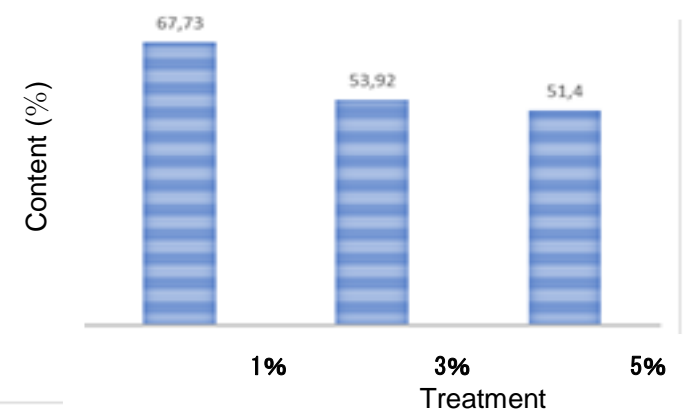

(b) Nitrogen content
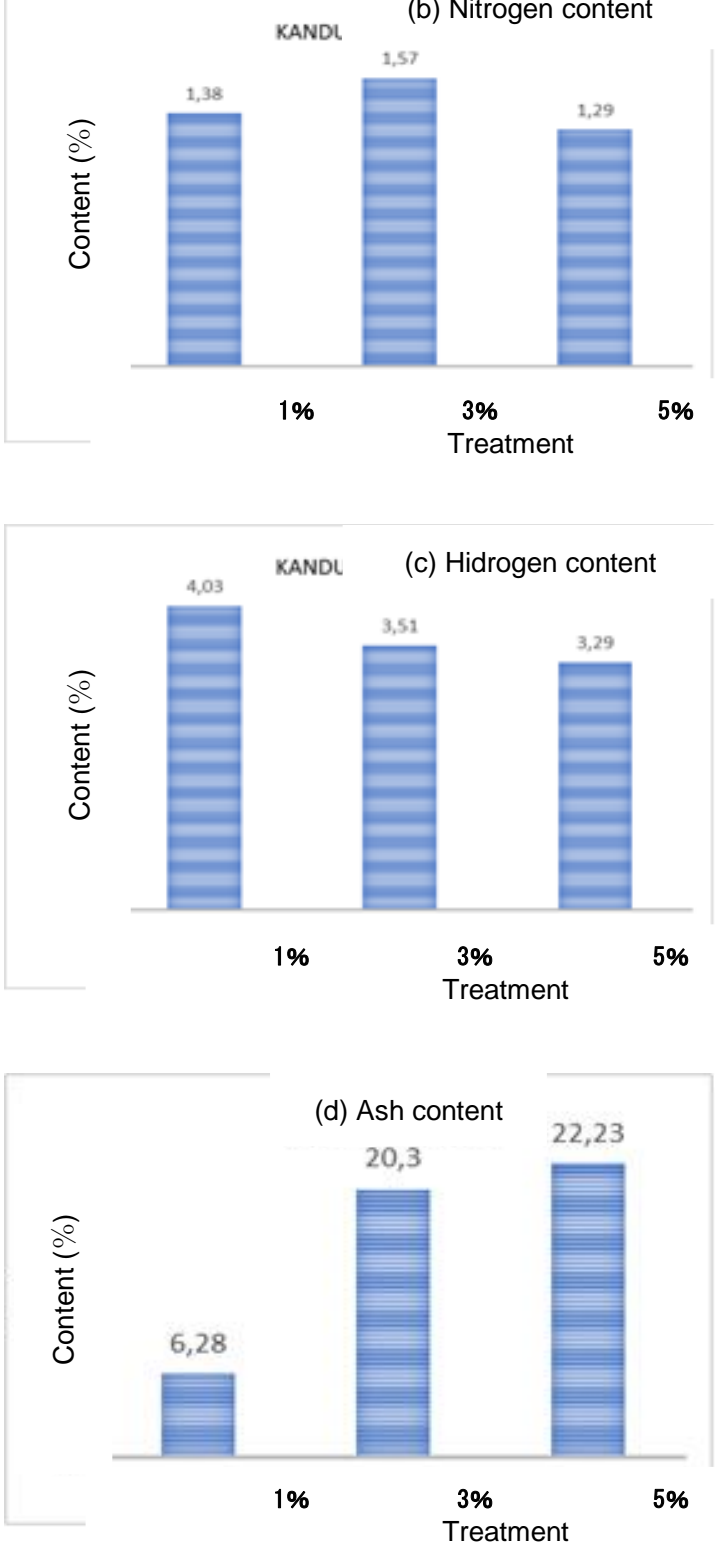

Figure 4. Variation of contents with $\mathrm{NaOH}$ concentration 


\section{(i) Carbon Content (C)}

The results of the analysis showed that the lower the use of $\mathrm{NaOH}$ activator concentration, the more activated charcoal carbon produced. This is due to the high concentration can give excessive reactions so that it can damage the structure of the pores in activated charcoal [6].

Based on the ultimate test results shown by Table 1 activated carbon with $1 \% \mathrm{NaOH}$ activation has the most Carbon (C) content of $67.73 \%$, while the activated carbon with $5 \% \mathrm{NaOH}$ activation contains the smallest Carbon (C) value with a value of $51.40 \%$. The carbon content in the activated carbon of the red chilli tree (Capsicum Anuumm L) waste will be addressed in Fig. 4(a) of Carbon Content.

Based on the graph, the carbon content for activation with $1 \% \mathrm{NaOH}$ activator fulfills the requirements of activated carbon SNI 06-3730-1995.

\section{(ii) Nitrogen $(\mathrm{N})$ content}

The value of Nitrogen $(\mathrm{N})$ with activation of $1 \% \mathrm{NaOH}$ has a value of $1.38 \%$, and the value of Nitrogen $(\mathrm{N})$ for activated carbon with activation of $3 \% \mathrm{NaOH}$ has the highest Nitrogen $(\mathrm{N})$ value of $1.57 \%$, for Nitrogen ( The smallest $\mathrm{N}$ ) is found on activated carbon with activation of $5 \% \mathrm{NaOH}$ with a value of $1.29 \%$. The content of Nitrogen (N) in activated carbon will be directed to Fig. 4(b) of Nitrogen content.

\section{(iii) Hydrogen content}

For the largest Hydrogen $(\mathrm{H})$ value found on activated carbon with $1 \% \mathrm{NaOH}$ activation with a value of $4.03 \%$, the smallest Hydrogen $(\mathrm{H})$ value is found on activated carbon with $5 \% \mathrm{NaOH}$ activation of $3.29 \%$, and for Hydrogen value $(\mathrm{H})$ with the activation of $3 \% \mathrm{NaOH}$ having a value of $3.51 \%$, the Hydrogen $(\mathrm{H})$ content in the activated carbon of the red chilli tree (Capsicum Anuumm L) waste will be shown in Fig. 4(c) of Hydrogen content.

\section{(iv) Ash content}

The highest ash level is found on activated carbon with $5 \% \mathrm{NaOH}$ activation with a value of $22.23 \%$ for the smallest level of ash found on activated carbon with $1 \%$ $\mathrm{NaOH}$ activation with an ash value of $6.28 \%$, and for activation with $3 \% \mathrm{NaOH}$ having ash value of $20.30 \%$, the content of ash in the activated carbon of the red chilli tree (Capsicum Anuumm L) waste will be addressed in Fig. 4(d) of the ash content graph.

The highest ash content found in activated carbon soaked with $\mathrm{NaOH}$ is due to the presence of $\mathrm{Na}^{+}$cations from activating materials that are bound to activated carbon, so that during heating a certain amount of $\mathrm{Na}^{+}$ becomes ash. On the other hand, it can be caused when activation occurs in contact with the air so that a further combustion process occurs where the activated carbon formed turns to ash. This ash level indicates the purity of the activated carbon produced [6].

\section{Conclusions}

The conclusions from the study "Characteristics of Active Carbon from Utilization of Red Chili Tree Waste (Capsicum annuum L) are as follows:

(i) The characteristics of activated carbon from the capsules of red chili (Capsicum annuum L.) analyzed using SEM observations and Ultimate testing are as follows: Test results on SEM for activated carbon from the red chili tree, at a concentration of $\mathrm{NaOH} 1 \%-5 \%$ higher concentration of $\mathrm{NaOH}$ activation, the pores formed will increase but make a lot of damaged pore walls, and the more voletile formed.

(ii) The Ultimate test results, the concentration of $\mathrm{NaOH}$ $1 \%-5 \%$ the higher the concentration of $\mathrm{NaOH}$ activation, the level of carbon $(\mathrm{C})$ in activated carbon decreases, and the variation of $\mathrm{NaOH}$ activation concentration to nitrogen (N) levels is fluctuating, the higher the concentration of $\mathrm{NaOH}$ activation in hydrogen $(\mathrm{H})$ in activated carbon will decrease, and the higher the concentration of $\mathrm{NaOH}$ variation, the higher the ash content in activated carbon.

\section{References}

[1] Hewindati, Y.T. et al. Hortikultura. Universitas Terbuka. Jakarta, 2006.

[2] Kuhad R.C., Singh A. and Ericksson K.E., Microorganisms and enzymes involved in the degradation of plant fiber cell walls. Delhi; Adv Biochem Eng Biotechnol, 1997.

[3] Darmawan S., Sifat arang aktif tempurung kemiri dan pemanfaatannya sebagai penyerap emisi formaldehida papan serat berkerapatan sedang. [tesis]. Bogor: Sekolah Pasca Sarjana. Institut Pertanian Bogor, 2008.

[4] Abdullah, Mikrajuddin and Khairurrijal. Karakterisasi Nanomaterial Jurnal Nanoscience dan Teknologi, 2008.

[5] Gusti Gilang Ramadhan Maulana, Lya Agustina, and Susi, Proses aktivasi arang aktif dari cangkang kemiri (aleurites moluccana) dengan variasi jenis dan konsentrasi aktivator kimia, Jurusan Teknologi Industri, Pertanian Fakultas Pertanian Universitas Lambung Mangkurat, 2017.

[6] i Setiawat and Suroto, Pengaruh bahan aktivator pada pembuatan karbon aktif tempurung kelapa, Jurnal Riset Industri Hasil Hutan Vol. 2, No. 1, 2010. 